\title{
THE VEHICLE AS A KEY FACTOR IN TRANSPORTATION ON THE EVE OF AN EPOCHAL PARADIGM SHIFT
}

\author{
Ralph Pütz ${ }^{l}$
}

UDC:62.838+004.2

DOI: $10.24874 / m v m .2017 .43 .04 .05$

\begin{abstract}
In the light of the 'megatrends' of electromobility and interconnection the car and commercial vehicle industry is facing dramatic changes which could lead to major upheavals. Triggered by ecological necessity and socially induced paradigm shifts, the understanding of mobility, the status of the environment, limited fossil resources, promising propulsion and fuel technologies as well as the increasing digitalisation and networking of all systems must inevitably be considered within a close system relationship. Sufficient technologies must therefore incorporate a corresponding sustainability in all areas: ecology, economy and social affairs for both subsystems as well as in the overall network context. Thus, for example, electromobility can only succeed in the transition to a comparable internal combustion engine in terms of economic and commercial maturity with a technology leap using post-lithium-ion battery technology. An improved lifecycle assessment can only be achieved in the medium to long term through extensive integration of regenerative energies in the electricity mix. Likewise, the interconnection which, at first glance, is inherent in and, ultimately, overarching within the transport system can probably only succeed in its ultimate aim of autonomous driving by overcoming high safety and regulatory hurdles in the medium to long term. In the context of these developments newly understood mobility and cross sector network synergy effects can be developed in the future on the way to a user perspective. In this respect, market shifts between the classic automobile manufacturers, innovative active suppliers and the IT industry are expected.
\end{abstract}

KEY WORDS: Electromobility, interconnection, lightweight design, megatrends, paradigm shift

\section{VOZILO KAO KLJUČNI FAKTOR U TRANSPORTU NA POČETKU EPOHALNE PROMENE PARADIGME}

REZIME: U svetlu "velikih zahteva" za korišćenje elektro pogona za kretanje, industrija putničkih i komercijalnih vozila suočava se sa dramatičnim promenama koje bi mogle dovesti do velikih preokreta. Podstaknuta ekološkom neophodnošću i socijalno indukovanim pomeranjima paradigme, Razumevanje mobilnosti, stanja okoline, ograničeni fosilni izvori, savremeni sistemi pogona i tehnologije goriva, kao i sve veća digitalizacija $i$ umrežavanje svih sistema, neizbežno se moraju uzeti u obzir u međusobnim odnosima koji su pod uticajem ekoloških zahteva i promena u društvu. Zbog toga se adekvatne tehnologije moraju primeniti da bi se dobila održiva rešenja u različitim oblastima: ekologiji, ekonomiji i društvenim odnosima u oba podsistema, kao i u celokupnoj mreži. Tako, na primer,

${ }^{1}$ Received October 2016, Accepted October 2016, Available on line first December 2017

Volume 43, Number 4, 2017 
prelazak na elektrovuču sa uporednog motora sa unutrašnjim sagorevanjem može se ostvariti u ekonomskom i tehnološkom kontekstu tehnološkim usavršavanjem post-litijumjonske baterije. Procenjuje se da se produženje životnog ciklusa baterija može postići samo srednjoročno i dugoročno kroz masovniju primenu različitih regenerativnih energija. Uspeh primene elektro vuče unutar transportnog sistema može se ostvariti ispunjenjem visokih sigurnosnih i regulatornih zahteva u srednjeročnom i dugoročnom periodu. U kontekstu ovih razvoja, nova shvatanja mobilnost i sinergijskih efekti međusektorskih mreža mogu se razvijati u budućnosti iz perspektive korisnika. U tom smislu očekuje se promena tržišta između klasičnih proizvođača automobila, inovativnih aktivnih dobavljača i IT industrije.

KLJUČNE REČI: elektromobilnost, međusobna veza, projektovanje lakih konstrukcija, veliki zahtevi, promena paradigme 


\title{
THE VEHICLE AS A KEY FACTOR IN TRANSPORTATION ON THE EVE OF AN EPOCHAL PARADIGM SHIFT
}

\author{
Ralph Pütz ${ }^{1}$
}

\section{INTRODUCTION}

The car and commercial vehicle industry is facing dramatic changes in the light of mounting 'megatrends'. The ecological necessities caused through climate change, tighter air quality aims and limited fossil resources and the change in social mobility awareness in industrialised nations towards freely combinable forms of mobility in connection with an increasing digitalisation and interconnection induce a potentially significantly changed portfolio for the future development of vehicle technology, in which the megatrends such as electromobility and interconnection are pushed forward as potential solutions (see Figure 1). These developmental priorities are ideally encompassed in a complementary sense by other technologies identified as promising such as the supporting lightweight design of electromobility, off-board-diagnostics automated through intercommunication or autonomous driving. In this respect, in an integrative total concept technologies must also conform to a comprehensive sustainability in all areas: ecology, economy and social systems. Despite the public and, above all, political hype concerning megatrends, the combustion engine has still not come to the end of its development and will continue to dominate in the medium term.

During the course of the conference "MVM 2016 - Motor Vehicles and Motor" in Kragejuvec all facets and topics mentioned here will be covered from modern, conventional propulsion up to and including alternative concepts for vehicles deemed promising for the future.

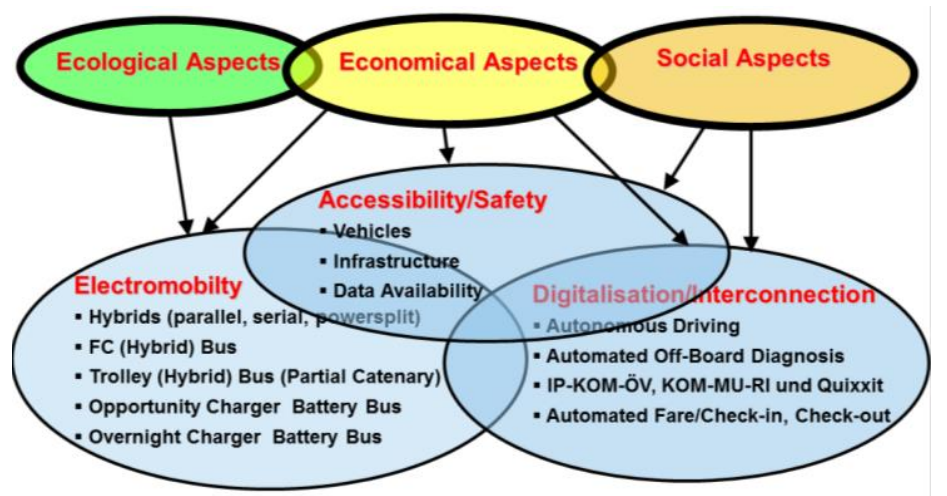

Figure 1. Actual megatrends in automotive industry, derived from action topics; here: example bus transport system (Source: BELICON)

${ }^{I}$ Ralph Pütz, Prof. Dr.-Ing. Landshut University, BELICON Institute for Commercial Vehicle
Research, Am Lurzenhof 1, D-84036 Landshut, Germany, ralph.puetz@ belicon-forschung.de 
In the following, by way of introduction to the conference, attempts will be made to shed light on the implications of the new megatrends starting with modern, conventional technologies using the example of the bus transport system in public transport, which the author has been researching at his institute, Belicon.

\subsection{Localization form and acoustic tensor}

In the course of the future development of propulsion concepts motivated by the new EURO VI limit rankings alternatives to the diesel engine, which has hitherto dominated route operated buses, are coming to the fore. On the one hand, these include conventional power drives such as the natural gas engine in conjunction with biogas of different generations and electrified power trains with the diesel engine in the form of hybrid concepts and preliminary concepts for pure electromobility, on the other. Thus, a comprehensive consideration of the effect on the environment is unavoidable. In particular, the reduction of particulate matter rated as carcinogenic (PM10 and smaller groups) and the gas nitrogen dioxide (NO2), which is classified as an irritant, are the focus of the policy, along with $\mathrm{CO} 2$ and its associated reduction in fuel consumption. In this context, however, not only individual power drives exclusively should be considered, but also all subsystems including fuel supply chains, vehicle production (and disposal) as well as maintenance.

\subsection{Combustion Engines for the near Future}

Since 1st January 2014 the new EURO VI limit level for all engines for heavy commercial vehicles has been introduced throughout Europe. EURO VI is the most comprehensive regulation to date by the EU to reduce local emissions from commercial vehicles. As opposed to the previous limit level, EURO V or the optional ranking EEV (Enhanced Environmentally-friendly Vehicle), particle emissions and nitrogen oxide (NOx) emissions should be reduced by $50 \%$ and $80 \%$ respectively during an engine type-approval test WHDC (World-wide Harmonised Duty Cycle consisting of a transient and stationary test cycle). Extensive practice measures taken by the author have proved that through the introduction of these new, more characteristic, practically-oriented test cycles for public transport it is possible to confirm that the low emission levels anticipated through the EU EURO VI ranking are actually achievable in genuine bus operation (see Figure 2). It can be stated that the most efficient EURO VI vehicles now demonstrate a 'Near Zero Emission' level whereby the ambient air is actually cleaned during intake by the engine. 


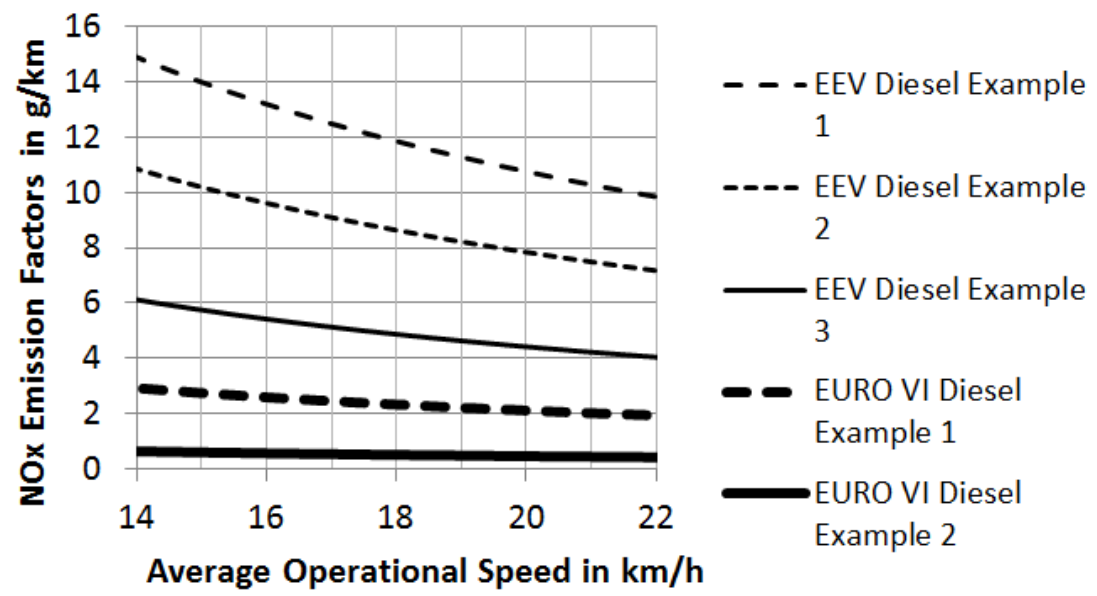

Figure 2. NOx-Emissions in relation to the cycle speed for diesel solo buses under EURO V/EEV and EURO VI regulations (Source: BELICON)

It is evident that with the EURO VI ranking propulsion systems with combustion engines demonstrate a highly significant improvement in local emissions (e.g. NOx) compared to previous levels. However, whilst a further reduction in global emissions and fuel consumption was verified by all manufacturers with diesel powertrains at

EURO VI, global emissions and fuel consumption with natural gas at EURO VI compared to EEV were likewise reduced depending on the input characteristics of the individual manufacturers, per contra with others it rose by around 30\%. Figure 3 shows the ratios of selected EURO VI buses for typical German city transport with an average cycle speed of $18 \mathrm{~km} / \mathrm{h}$, which corresponds to the SORT 2 (Standardised On-Road Test) cycles.

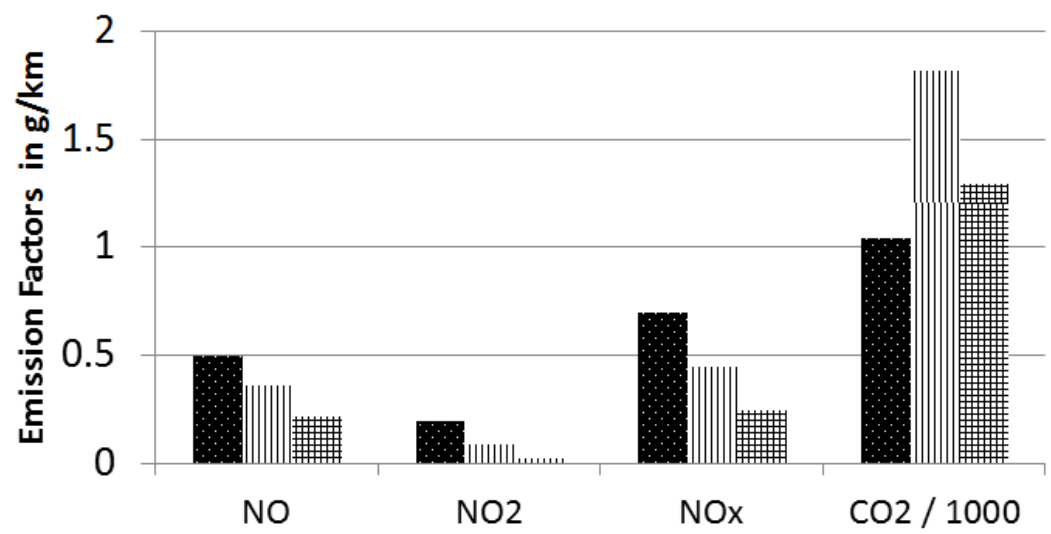

Diesel EURO VI, Example IIII CNG EURO VI, Example 1

\# CNG EURO VI, Example 2

Figure 3. Comparison of local and global emissions as well as consumption by buses under different limit levels at a nominated cycle speed of $18 \mathrm{~km} / \mathrm{h}$ on a comparable route (souce: BELICON) 


\subsection{Development of the "Bridge Technology" Hybrid}

The potential and opportunities for hybrid technology are closely linked to the characteristics of energy storage technology. The advantages of ultracaps (high performance condensors) are high power densities, i.e. a rapid energy input and output; the disadvantage here is the low energy density and the related limited total energy intake. By way of contrast to this, batteries demonstrate a high energy density and thus high energy storage capability although they have a lower power density. Current critical points are the still relatively low cycle stability, lifespan limitation due to greater sensitivity to temperature ratios and fluctuations in voltage, a higher control input and high costs. A compromise could be offered by so-called Li-Caps in the threshold between Ultacaps and Li-Ion batteries. Hybrid concepts can only then exhaust their full potential if, in addition to the actual brake energy recovery, additional functionalities such as downsizing the combustion engine, start/stop function, electrification of the auxiliary units and an overriding, route dependent energy management could consequently be implemented. If only brake energy recovery is anticipated, then the energy saving remains limited to a maximum of $10 \%$. Only through the implementation of all the above mentioned hybrid functionalities can energy savings of around $30 \%$ be realised. The basic hybrid structure itself (serial, parallel, power split) has proved to be less critical in practice. In order to demonstrate the efficiency of current hybrid buses, the global emissions of currently used conventional and hybridised articulated buses based on SORT 2 (average cycle speed of $18 \mathrm{~km} / \mathrm{h}$ ) are compared in the following Figure 4.

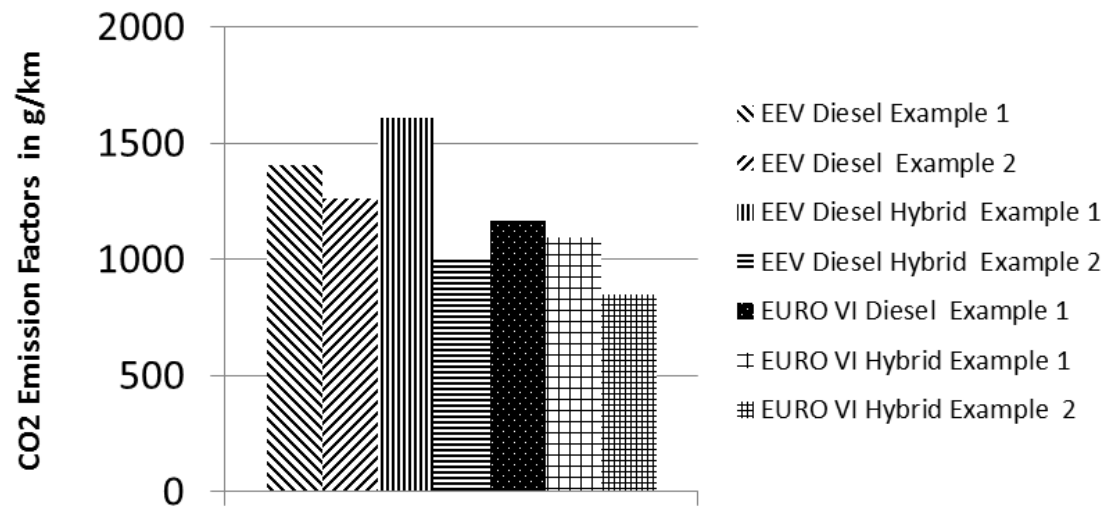

Figure 4. Comparison of $\mathrm{CO}_{2}$ emissions of selected articulated buses with a normalised cycle speed of $18 \mathrm{~km} / \mathrm{h}$ (source: BELICON)

With an economic evaluation taking into account vehicle costs (vehicle procurement, maintenance and fuel) significant additional costs are reflected for hybrids despite fuel savings due to higher investment and maintenance costs. The comparatively moderate ecological improvements of hybrid technology compared with conventional EURO VI buses must be 'bought' over an input period of 12 years with significant additional costs. It should be noted that the current availability of hybrid buses is generally not at the same level as conventional vehicles and reserve vehicles must be kept in stock for heavy/frequent usage.

In order that the hybrid technology can achieve economic viability at the same level as conventional propulsion systems, the investment costs for this type of technology must be reduced significantly. By way of example, Figure 5 shows the conditions for the 
economic viability of a city hybrid solobus waiving public funding subsidies. According to this, with a comparable economic viability, the addtional vehicle investment costs compared to conventional buses are merely around $€ 30,000$ (by comparison: the additional investment costs of hybrid solo buses are currently between $€ 75,000$ and $€ 130,000$ ).
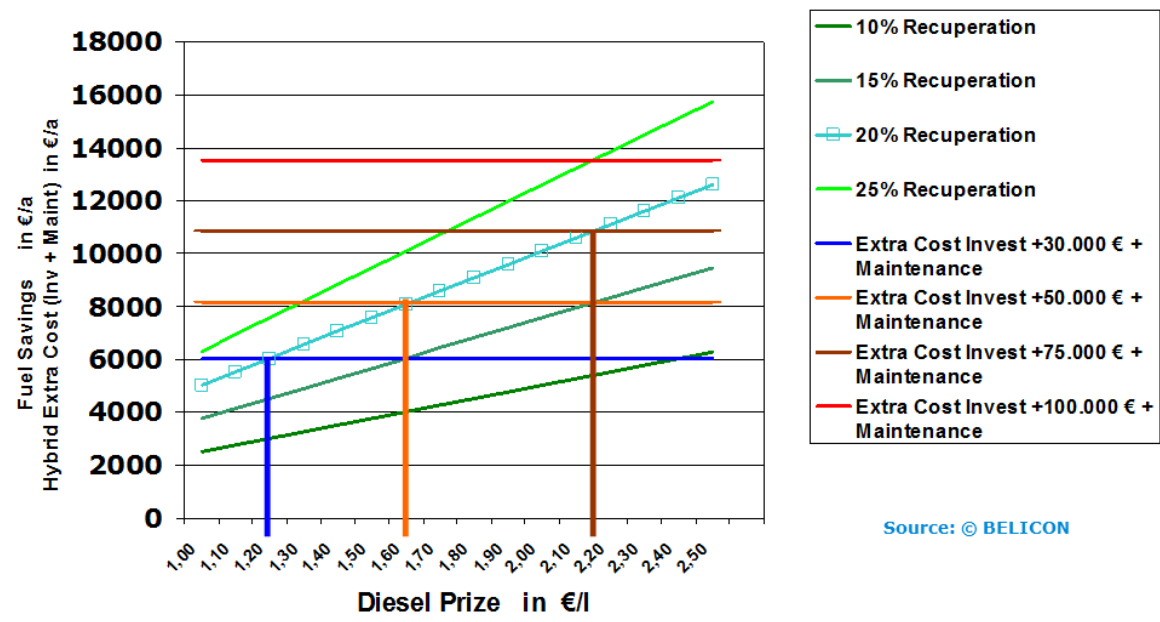

Source: 다 BELICON

Figure 5. Fuel saving versus additional hybrid costs depending on diesel price and the recuperation rate (example: city solobus) (source: BELICON)

\subsection{Actual Stage of Development and potential Advancement of Electromobility}

As a rule, electromobility represents an individual system for each transportation company and its circumstances, whereby vehicle and power technology, battery type, energy intake and loading technology and operational pattern on the respective route topology must be determined. The input of battery and fuel cell buses is still very limited today although extensive marketing measures may make it appear otherwise. As this type of technology becomes more ready for operational mass production, its use will become increasingly accelerated in the future. Intensive use of battery and fuel cell buses is currently only possible for those transportation companies who can draw on extensive public funding.

In the following, promising alternative power systems for the 'electromobility" category will be assessed both ecologically and economically. These include:

- Opportunity Charger (aka: E Bus Opportunity, OPC); has a smaller battery and has to be recharged en route regularly. This requires fast charging with high power and voltage levels. Two charging stations per route with ten buses are generally used. A second battery during operational lifespan is also currently required.

- Overnight Charger (aka: E Bus Overnight, ONC); has a big battery and is therefore only charged slowly overnight with $400 \mathrm{~V}$ technology at the bus depot itself. A second battery during operational lifespan is also currently required. 
- Fuel Cell-Hybridbus (FCH); conventional fuel cell buses are no longer relevant. A second battery during the operational lifespan is currently required. Due to the reduced fuel cell lifespan a replacement fuel cell stack can become necessary.

- Trolley-Hybridbus (aka In-Motion-Charger, TRH); conventional trolley buses will no longer be relevant in the future. A second battery is required during operational lifespan.

A total ecological evaluation is done here following the 2009/33/EG directive (directive on the promotion of clean and energy efficient road transport vehicles for public transport) using the totaling of external costs from local and global emissions of all subsystems including:

- Fuel supply (WTT; Well-to-Tank),

- Vehicle production

- Vehicle operation (TTW; Tank-to-Wheel) and

- Maintenance.

It thus characterises the environmental relevance of the different propulsion system variants investigated on an up-to-date basis. In this case, as is usual current practice, fuels from fossil sources were used for all variants. Regenerative fuels have not yet been introduced in electromobility projects and possibly accounted for in calculation. If the talk in different projects still refers to 'green electricity', then this merely relates to 'balanced green electricity'. The ecological total assessment (see Figure 6) demonstrates that, for a comprehensive sustainability, no improvements can currently be achieved by alternative electric propulsion variants taking into consideration local and global emissions as well as energy consumption. In the medium term therefore, diesel technology remains the first choice for public transport. In total the conventional power diesel EURO VI and natural gas

EURO VI equate to the opportunity and overnight buses. An additional ecological potential is offered through the use of biogas and biogenic synthetic diesel fuels as well as regenerative electricity and hydrogen which should be actively harnessed in the future. As a result of the energy transition through discontinuation of nuclear power stations and the substituted use of brown coal, the electricity mix in Germany has actually worsened ecologically albeit temporarily. 

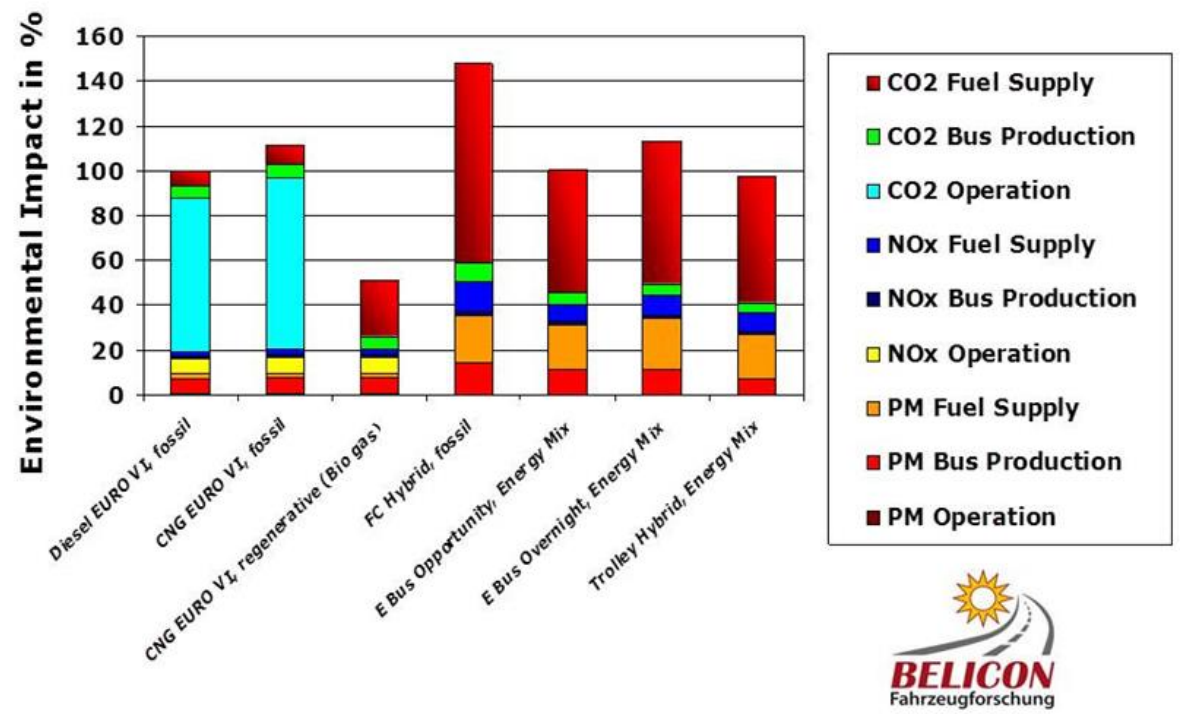

Figure 6. System-related environmental relevance 2016 using external costs of a bus fleet in a total lifecycle (12 years) in accordance with 2009/33/EG (source: CBELICON)

In the following text there is an economic analysis of electrobus concepts currently under discussion compared to the EURO VI diesel bus for reference. The cost of the vehicles per bus kilometre is made up from the apportioned costs for:

- vehicles

- infrastructure

- replacement investment (e.g. for a change of battery during the lifespan of the bus)

- energy

- maintenance and repairs.

The assumed vehicle costs are pieced together to objectify the costs of the components used (vehicle configuration). Thus, calculations are made for electrobuses based on both automotive electro technology (electric motors, power electronics) with a 12 year expected lifespan as well as the sensitivity of use with a more cost intensive, but more durable (20 year lifespan) rail technology. If, in the future development of electromobility, there is a market penetration in accordance with experience from other key technologies in the automobile sector, then a market penetration over time as shown in Figure 7 would result. The time horizons 2015 (present day) and 2025 (medium term) are applied for the economic evaluations. 


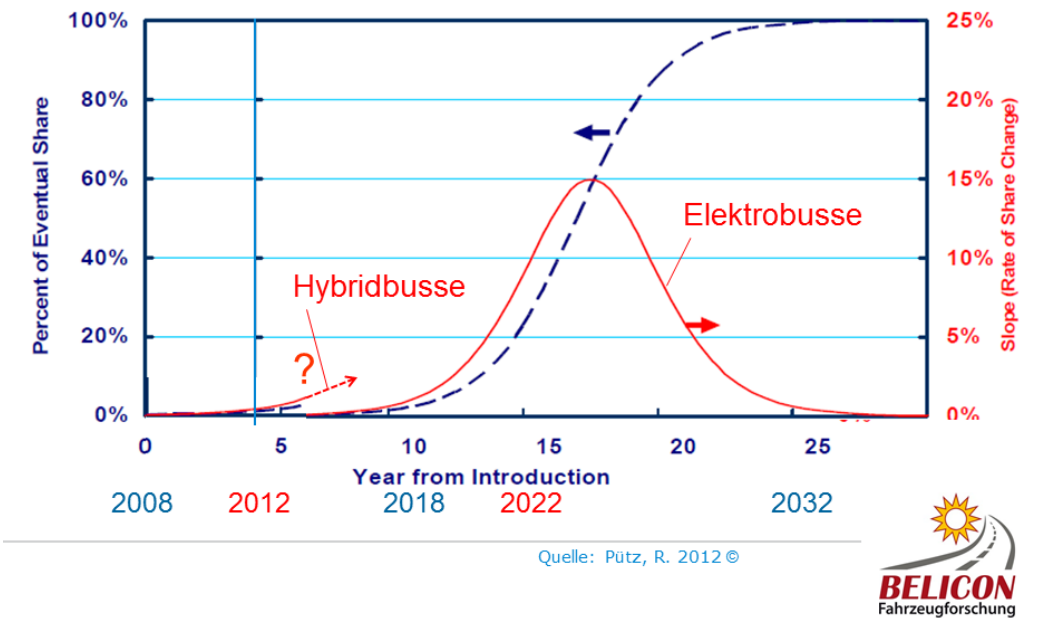

Figure 7. Model approach towards expected market penetration of electromobility (source: BELICON)

The total economic evaluation - differentiated on the basis of automobile and rail technology as well as for the time horizons of 2015 (present day) and 2025 (medium term) is shown in Figure 8. With a trolley hybrid bus the overhead line is included for $50 \%$ of the total route.

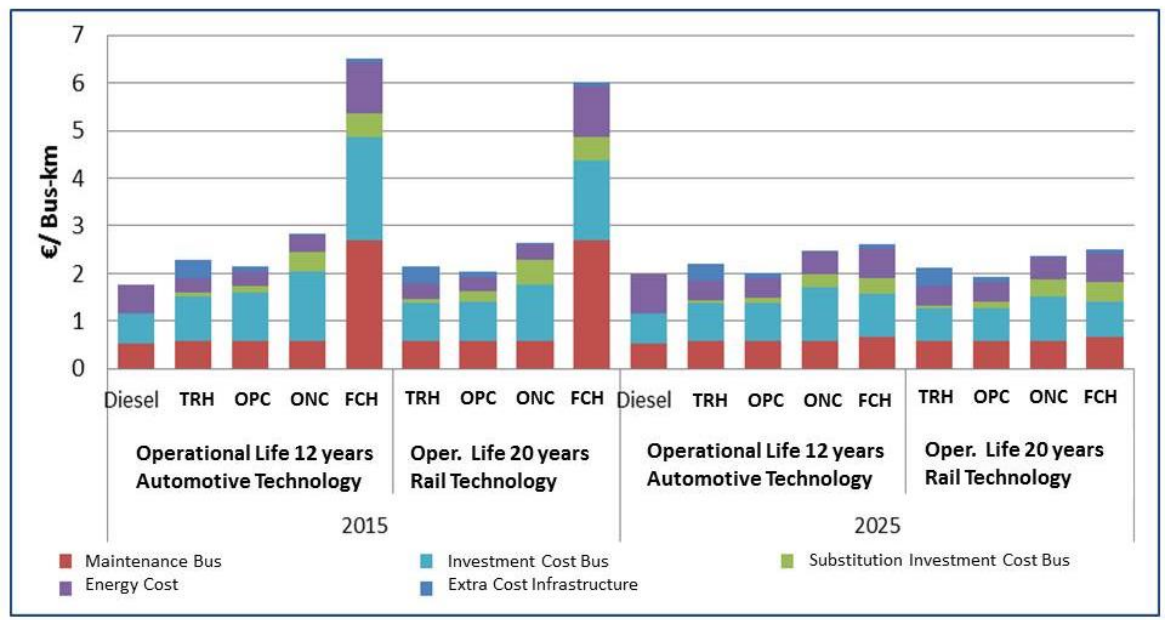

Figure 8. Cost comparison of propulsion technologies of articulated buses (lifecycle costs without driver costs) (source: IFEU/BELICON)

From this it is clear that all current electrobus technologies are significantly more expensive than the conventional EURO VI diesel articulated bus. In the medium term (in 2025) electrobuses will become more economically competitive - in particular, as a result of the assumed increase in diesel prices as well as a reduction in the cost of batteries. It is also recognisable that the costs of the electrobus concepts will align with one another in the long term. With regard to vehicle-km the Trolley-Hybrid (TRH) and Opportunity Bus (OPC) 
options are the most cost effective electrobus technologies both currently as well as in 2025 . Concepts with a greater flexibility (no route-based infrastructure) such as fuel cell hybrid $(\mathrm{FCH})$ and overnight bus (ONC) are more expensive in 2025 than TRH and OPC buses (25 $\mathrm{ct} / \mathrm{km}$ or $41 \mathrm{ct} / \mathrm{km}$ compared to the GL [12 year lifespan]).

The additional costs of the trolley hybrid bus compared to the opportunity bus (2015: 13ct/km, 2025: $20 \mathrm{ct} / \mathrm{km}$ [12 Jahre Lebensdauer]) result, in particular, in greater expenditure for the overhead line infrastructure. Without infrastructure costs i.e. if an investment has already been done for this, then the trolley hybridbus (TRH) represents the most cost effective electrobus system within the entire study. As the trolley hybridbus can draw electricity for propulsion and for heating/air conditioning as well as charging the battery from the overhead line, this has operational advantages compared with the overnight and opportunity bus concepts since these must draw energy required for heating/air conditioning from the limited reserves of the battery storage unit, which can significantly reduce the overall coverage. A 20 year operation of electrobuses leads - despite higher procurement costs for this type of bus - to a reduction in costs per bus-km for all electrobus technologies taken into consideration. Nevertheless, this cannot close the economic viability gap with the currently established diesel bus (2015). At best, in the medium term (2025), a trend towards convergence can be expected.

An important advantage of all electrobus concepts is the reduced noise emissions compared with combustion engine drives. Measurements taken in practice confirm that, when leaving the bus stop electrobuses demonstrate a noise level which is $5 \mathrm{~dB}(\mathrm{~A})$ lower, see Figure 9.

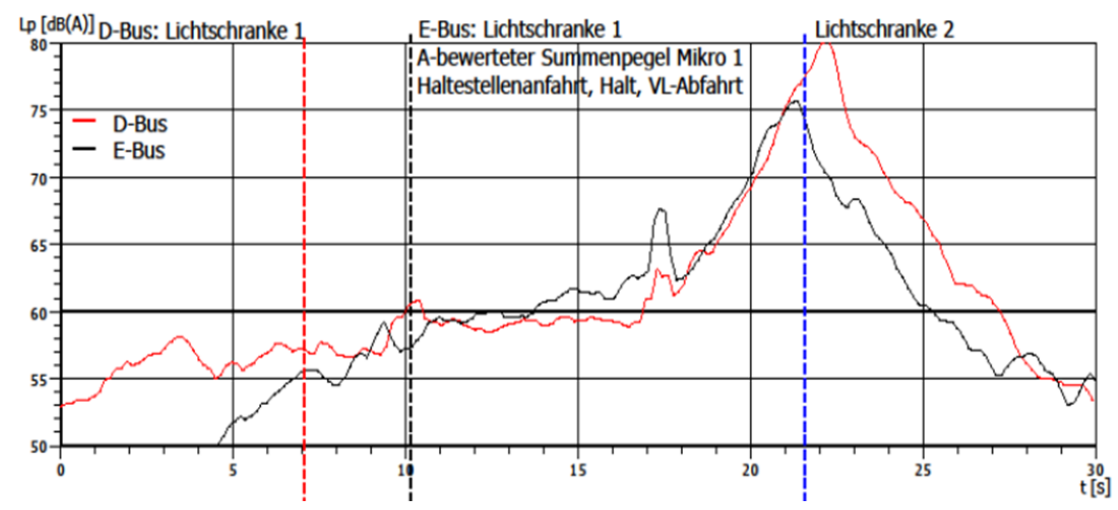

Figure 9. Comparison of noise level of diesel and battery bus (source: BELICON)

\subsection{Conclusion on Propulsion System Development}

The ecological and economic analysis of currently implemented or tested alternative propulsion technologies for route operation buses has demonstrated that conventional "near zero" powertrains with diesel and natural gas will continue to remain the first choice for route operation buses for the foreseeable future as it enables transportation companies to act both economically and taking the environment into consideration. It is clear that electromobility with batteries will likely only be able to penetrate the market following the anticipated technology leap towards Li-Ion successor technologies (Li-S?) after 2026 to 2030 (see Figure 10). 


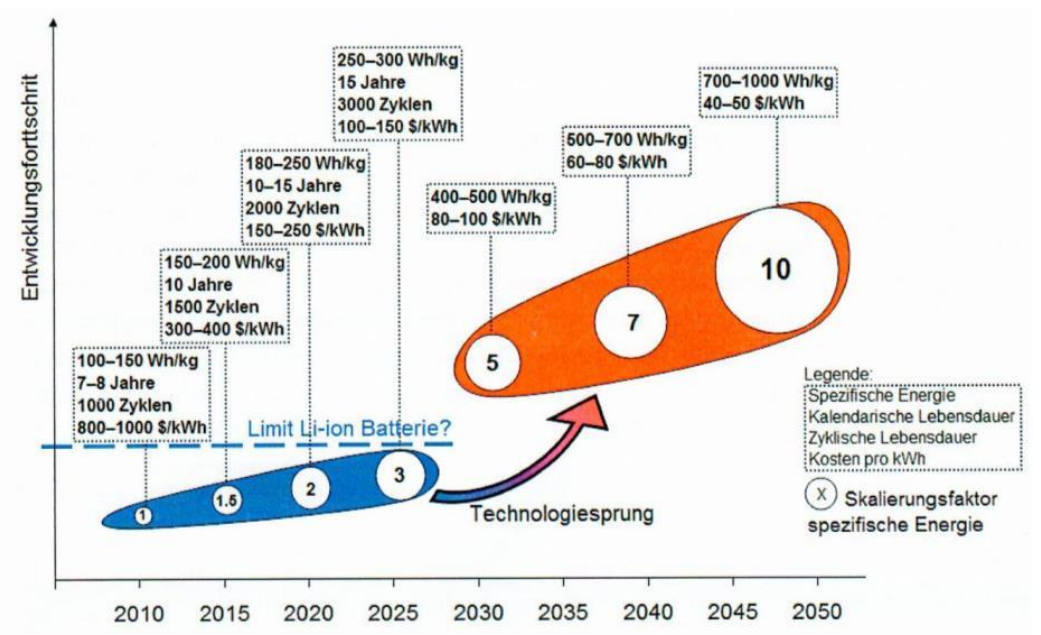

Figure 10. Aggregated technology road map for Li-Ion batteries (source: Schulz, A., 2015)

Nevertheless, the existing potential for alternative bus propulsion systems must be completely exhausted in the near future. Therefore, it is important that some transportation companies and local authorities are ready to test these buses and thus obtain relevant experience which will serve the further development of alternative power for all transportation companies (best practice in Serbia: Beograd Transport Company). This is, however, only possible if extensive means from public funding are continually made available.

What is undisputed is the fact that all sectors of our society - including local public transport - must be involved in the creation of a worthy environment for generations to come. A decisive factor in this case, however, is finding an economically practicable way towards this goal. Big transport companies have more favourable conditions to lead the way forward due to their greater potential and can become involved as pioneers in the testing of alternative power compared with smaller transport companies which could be overextended due to lower vehicle and personnel capacity. One should not ignore the fact that all current alternative propulsion technologies are significantly more expensive in terms of procurement and maintenance compared with tried and tested diesel and natural gas drives due to their development and number of units - even in the age of EURO VI. It should also be questioned as to whether the combustion engine can be replaced in the long term by electromobility. Rather more it is to be expected that certain areas of application will explicitly require coordinated drive technologies. In longer route areas the combustion engine will dominate in the long term. Nevertheless, the danger exists for the car and commercial vehicle industry that electromobility could become the "Trojan horse" of classic vehicle manufacturers since the batteries occupy a large share of the value of the vehicles; however the manufacturers of the battery cells have established themselves in east Asia. Whether or not it will be sufficient for the vehicle manufacturer to be responsible merely for the quality monitoring and assembling of the battery cells remains open. An engagement with strategic partnerships in the development of post-Li-Ion battery technology would certainly be expedient. Also, the route towards electromobility could generate a migration from suppliers such as Bosch, Siemens or ZF - to name a few German companies by way of 
example here - to veritable vehicle manufacturers. The same applies to leading companies in the IT industry such as Apple or Google.

\subsection{IT Technologies and Networking}

Within the context of a change in understanding of mobility, in particular for the younger generation, the existing competition between individual and collective transportation companies has softened and been replaced by a service level cooperation. The customer is no longer interested in simply owning vehicles, but rather more in the preference of mobility. Thus, it can be expected that the classical transport operators as well as the classical car manufacturers concur and start to develop towards being a provider of mobility services. Car2Go and DriveNow are the first examples. So it is to be expected that the IT sector will become increasingly important since it can significantly support and operate the development of driver assistance categories and autonomous driving, telematics and off-board diagnostics as well as infotainment. In view of the enormous opportunities which can result within the context of electromobility and the trends towards vehicle networking the IT sector can be equally significant, if not more important, to the vehicle manufacturer in the car and commercial vehicle sector.

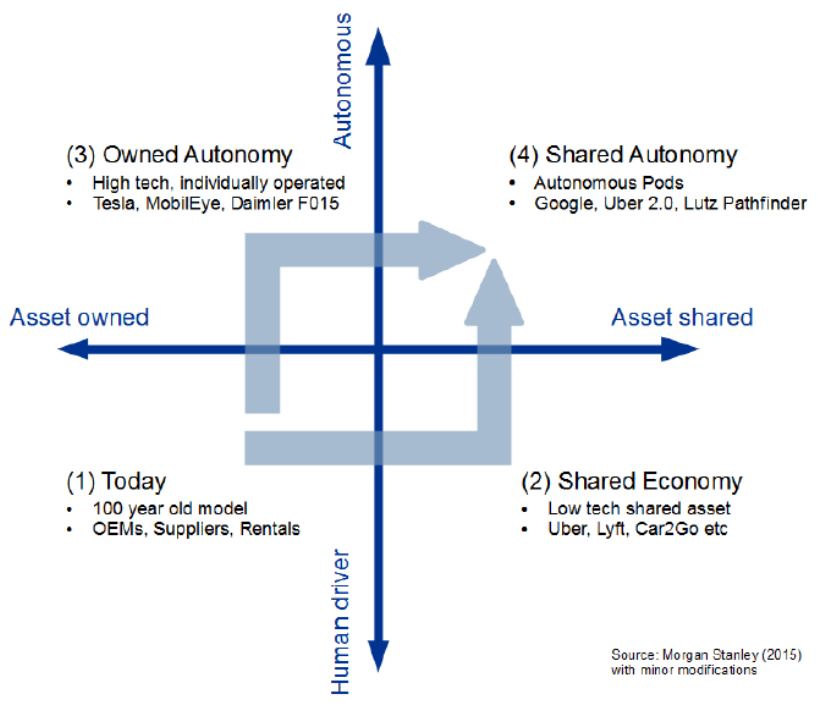

Figure 11. Change in understanding of mobility encourages further IT developments as autonomous driving (source: Morgan Stanley, 2015)

\subsection{Driver Assistance Systems and Autonomous Driving}

In controlled environments - such as agriculture or the mining industry - selfdriven vehicles have already been implemented with success. Work cost savings of up to $90 \%$ and significant reductions in $\mathrm{CO} 2$ have resulted. Logistics can also use fully automated trucks, for example, to enable better fleet capacity utilisation and create more efficient supply chains. Practice tests by vehicle manufacturers confirm this. In addition to the positive economic and ecological effects, socio-economic improvements through a reduced 
risk of accidents and improved transport flows can also be expected. In actual fact, fully autonomous vehicles and robots are based on similar technologies so that synergies will accelerate development on both sides. Public service buses are, however, still a long way off from regular autonomous driving. The first step within the legal hurdles to overcome is driver assistance when approaching a bus stop. Securing a minimal distance from the kerb to improve passenger boarding is feasible in all cases. The bus driver should not initially be dispensed with since safety is paramount during practice runs so that the driver can intervene at any time. In the long term autonomous driving should significantly improve the life-cycle cost and availablility through dispensing with the need for a driver. Simultaneous use of a driver and technology for autonomous driving do not make sense objectively.

Attempts to realise autonomous driving have been made since the 1990s through mechanical, inductive and optical lane guidance projects. Autonomous driving is currently being publicised in the public service bus sector through EvoBus which has a system based on HighwayPilot which is also being tested in long distance driving for trucks on German motorways. Recognition of obstacles and pedestrians and the combination of priority at traffic lights are currently being tested worldwide, see Figure 14.

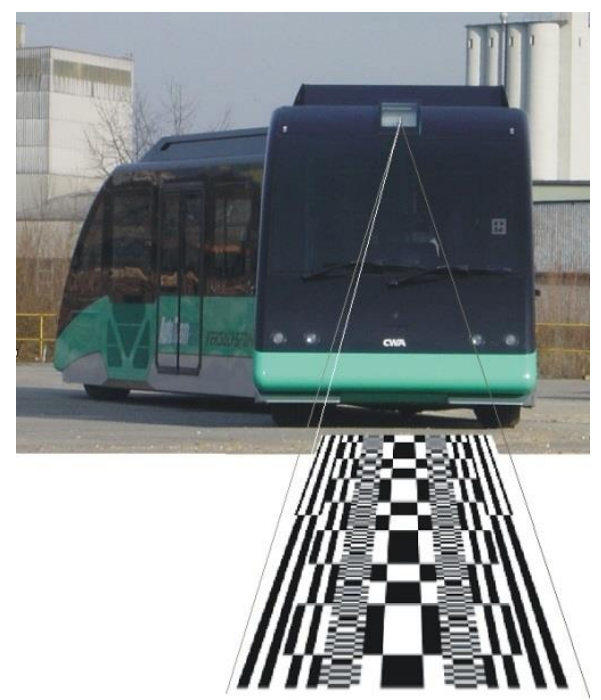

Figure 12. The Autotram - autonomous driving with barcode signals (source: Fraunhofer IVI, 2005) 


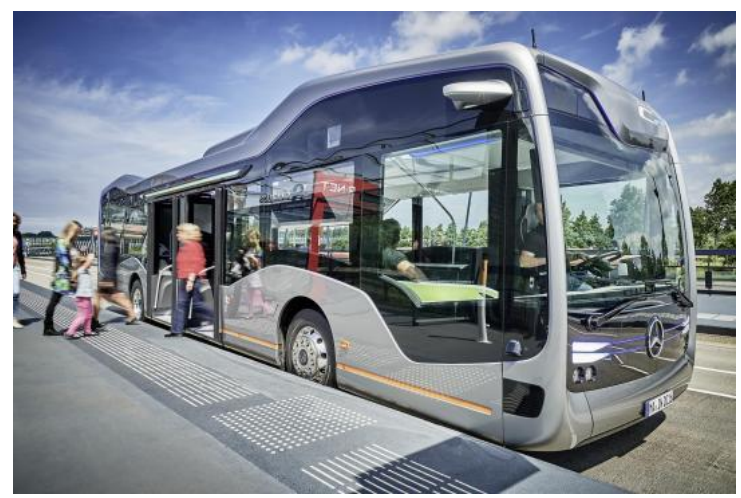

Figure 13. FutureBus - Autonomous driving project by EvoBus with 10 Cameras (source: EvoBus, 2016)

- How far will the road user get on his given path within a certain time interval?

$\Rightarrow$ Longitudinal probability distribution: $f(s)$

- How large is the lateral deviation of the movement from the given path

$\Rightarrow$ Lateral probability distribution: $f(\delta)$

- Independency assumption:

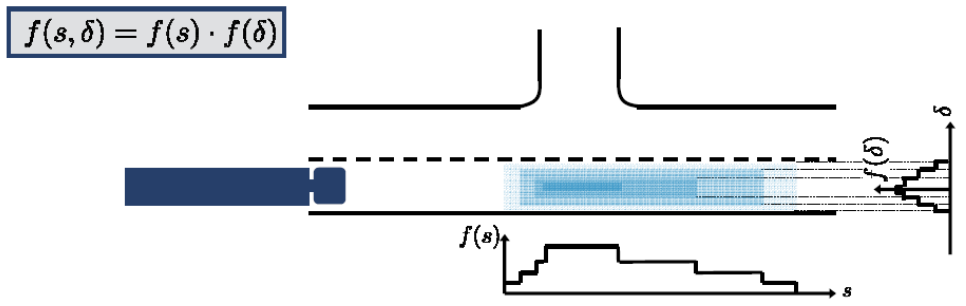

Figure 14. Prediction for the (Ego) environmental performance (source: Daimler, 2011)

On-demand public transport would offer a further level of migration, but it's still a long way off. In Hamburg, Germany, a possible test field is currently being developed for autonomous driving in cooperation with VW. The technical requirements of an autonomous urban bus are almost identical to those of an autonomous car; however, it is anticipated that buses will be on the road autonomously sooner than cars since the former often have their own separate lanes and, therefore, less interaction with other vehicles can be expected. Carto-car communication with referenced, coordinated routes would be a further level of development. 


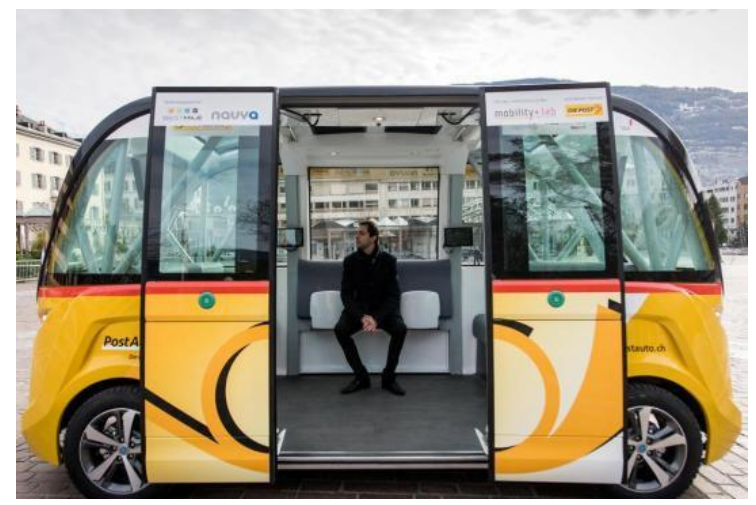

Figure 15. Example for autonomous shuttle bus (source: Postauto Schweiz AG, 2016)

\subsection{Automated Remote Maintenance}

Automated off-board diagnostics such as those for fleets of aeroplanes on the basis of an open platform is one of the most promising options for further improving the efficiency of transportation companies. The prerequisite for automated off-board diagnostics is the willingness of the vehicle manufacturer to make accessible all relevant state variables which are available on the CAN databus (Controller Area Network) on an open diagnostic platform for evaulation in order to thus identify complex faults. These faults are then taken off board automatically by an EDP-supported maintenance planning and fed in for execution with automatic scheduling by maintenance personnel, materials, progress status and optimal timing. This leads to a reduction in time taken to detect faults and, thus, to a reduction in personnel ratios. Furthermore, serious faults can be prevented through early diagnosis and targeted indications to drivers which, in turn, results in reducing the subsequent costs of rectifying the faults as well as the amount of time the vehicle is out of service, so the vehicle has greater overall availability. The optimisation of maintenance schedules through predictable scheduling further reduces the personnel ratio. Ultimately, a "prematurely averted" need for maintenance results in greater vehicle quality and availability. The prompt availability of spare parts by connected manufacturers' logistic systems also leads to further best practice optimisation.

Through targeted instructions to transport personnel for economic driving with direct feedback in the central display of the driver cab, a reduction in fuel consumption of between 5 and $10 \%$ can be expected on the basis of values achieved in testing. Furthermore, due to the scheduling of maintenance work and higher vehicle quality with established offboard diagnostics, a reduction in the vehicle reserves is possible. 


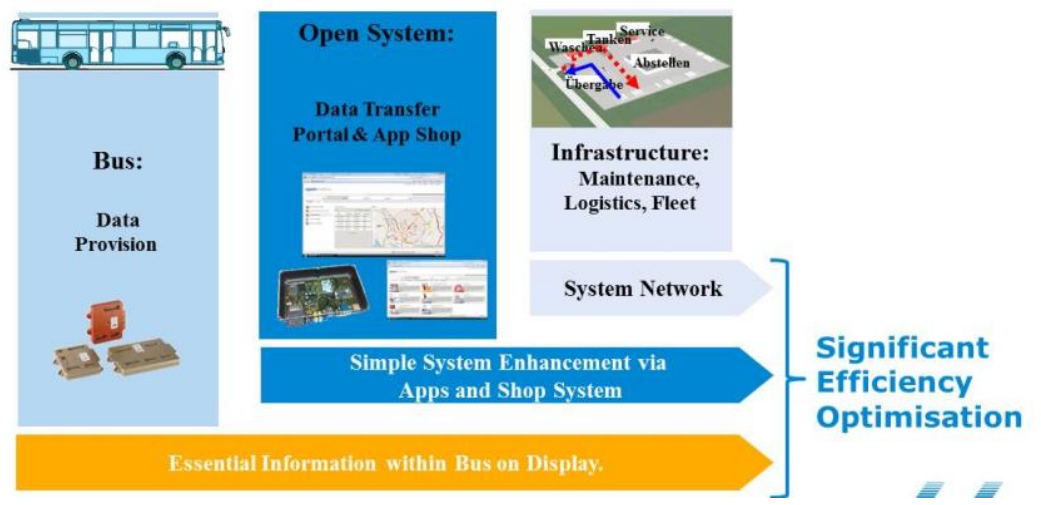

Figure 16. Increases in efficiency through off-board diagnostics (source: Continental, 2011)

\subsection{Conclusion on IT Developments and Networking}

The increased digitalisation and changed requirements of electrotechnology and IT between the mechanical engineering sector and the automobile industry resulting from the networking of systems open, in particular to the IT sector, new areas of business with the potential tendency of overall leadership even in the vehicle industry. These must be adapted to academic education since cross sectoral competencies will be unavoidable in the future.

\subsection{Lightweight Design}

One of the complementary key technologies in conjunction with electromobility is lightweight design which also plays an important role with conventional vehicles, but which is becoming increasingly significant in the electromobility sector. In order to achieve a greater scope without passenger capacity being adversely affected and without having to recharge en route it is an urgent necessity that the weight of the vehicle is reduced as far as possible. Carbon fibre reinforced plastic in conjunction with high strength steel and light alloys require new construction and manufacturing technology due to the hybrid structures. A one tonne reduction in weight would enable public service buses to save fuel and thereby reduce the related $\mathrm{CO} 2$ by $4 \%$. In other words: a lightweight bus with a saving of 3 tonnes in weight has the same effect as an average hybrid system in public transport operation, which saves only $12 \%$ in fuel on average annually.

\section{CONCLUSIONS}

The car and commercial vehicle industry is facing dramatic changes due to looming "'megatrends“. Through climate change, air quality targets and limited fossil resources, previously mentioned ecological necessities and a changed commercial understanding of mobility in industrialised nations including freely combinable forms of mobility in conjunction with an increasing digitalisation and networking in an age of information trigger a significantly different portfolio of requirements for the future for the continued development of vehicle technology. This offers new actors from the IT industry sector and also from the supply industry the opportunity to endanger the established 
positions of classical vehicle manufacturers and to take on responsibility for the development as a whole. On the other hand, cross-departmental, competency-based partnerships can shift overall responsibility to the forefront. A conditio sine qua non on the way to networking would be a forced standardisation e.g. with the charging infrastructure with electromobility, with the cross-vendor automated off-board diagnostics etc. in order to provide developments on a wider basis and thus to improve the economic viability. European industry still has the opportunity - in the face of an obstructive background of an ageing population and a leap forward by east Asian concerns in battery technology - to maintain its technical-economic progress. For this, a new strategical alignment and a corresponding active design is essential. This also affects universities which have to adjust to the high level of European academic education towards an intensified interdisciplinary approach.

No one knows what will happen in the future, but the best way to predict the future is to actively create it yourself! In this sense, I would like to wish the delegates of this conference insightful lectures, interesting meetings and discussions and an engaged creativity in practice.

\section{REFERENCES}

[1] R. Pütz, Modell zur ökologischen und ökonomischen Analyse und strategischen Optimierung von Linienbusflotten, Düsseldorf: Alba Fachverlag, [Model for the ecological and economic analysis and strategic optimisation of public service bus fleets], 2010.

[2] R. Pütz, Einführung in die Linienbustechnik, Köln: Alba Fachverlag, [Introduction to public service bus technology], 2012.

[3] F. Bergk, U. Lambrecht, R. Pütz und H. Landinger, Analyse der Lebenszykluskosten von Hybrid-Oberleitungsbussen, Heidelberg, IFEU/BELICON, [Analysis of the lifecycle costs of hybrid overhead line buses], 2015.

[4] F. Bergk, U. Lambrecht und R. Pütz, Potenziale des Hybrid-Oberleitungsbusses zur Nutzung regenerativer Energien und Steigerung der Energieeffizienz, Heidelberg, IFEU/BELICON, [ Potential for hybrid overhead line buses for using regenerative energies and increasing energy efficiency], 2015.

[5] R. Pütz, Status Quo und Potenziale elektrifizierter Antriebsstränge im Omnibusbereich, München, [Status quo and potential of electrified powertrains in the public bus sector], 2016.

[6] R. Pütz, Potenziale des Oberleitungsbusses zur breiten Einführung der Elektromobilität im ÖPNV, Berlin, [Potential for overhead line buses for wider introduction of electromobility in public transport], 2016. 